\title{
Effect of periodic fasting on growth and feed efficiency in Giant Freshwater Prawn (Macrobrachium rosenbergii, de Man 1879)
}

\author{
Waskito Dwi Utomo ${ }^{1, a}$, Riza Rahman Hakim ${ }^{1, b,{ }^{*}}$, Ganjar Adhywirawan Sutarjo ${ }^{1, c}$ \\ ${ }^{1}$ Aquaculture Department, Faculty of Agriculture and Animal Science, University of \\ Muhammadiyah Malang, Indonesia. \\ awaskitodwiutomo@gmail.com brizarahman@umm.ac.id cganjar@umm.ac.id \\ ${ }^{*}$ Corresponding author
}

\section{ARTICLE INFO}

Keywords:

Feed efficiency

Growth

Macrobrachium

rosenbergii

Periodic fasting

\section{ABSTRACT}

There are obstacles in the aquaculture business that is still often faced by farmers, one of the challenges is the high price of commercial feed. Feed as an energy source for growth is a reasonably high-cost component in production that reaches of 40 to $89 \%$. In the control of food for efficiency, it could be done by the fasting method. This research was aimed to analyze the effect of periodic fasted of giant prawn (Macrobrachium rosenbergii) against growth and feed efficiency. This research was conducted at IBAP Installation, Probolinggo District, East Java Province. The experimental method used completely randomized design with five treatments and three replications, such as; P0: feeding without fasting (as control), P1: a-day fasted, a-day feeding, P2: a-day fasted, two-days feeding, P3: a-day fasted, three-day feeding, P4: a-day fasted, four-days feeding, P5: a-day fasted, five-day feeding. The results showed that periodic fasted of $M$. rosenbergii no significant effect on daily growth rate, absolute weight growth, and feed efficiency. However, by looking at the rate of growth, this fasting method could be used as an alternative to saving feed. The P5 showed the most effective in increasing daily growth rate, absolute weight growth, and effectiveness of giant prawn feeding. The strategy of periodic fasted to increase the production of giant prawns should consider the other supporting factors such as ideal water quality $(\mathrm{pH}$, temperature, and $\mathrm{DO})$, proper stocking density, and feeding periods on schedule.

How to cite:

Utomo WD, Hakim RR, Sutarjo GA. 2019. Effect of periodic fasting on growth and feed efficiency in Giant Freshwater Prawn (Macrobrachium rosenbergii). IJOTA. 2(2): 53-58.

DOI: https://doi.org/10.22219/ijota.v2i2.6679

Copyright (C) 2019, Utomo et al. This is an open access article under the CC-BY-SA license

\section{Introduction.}

Giant Freshwater Prawn (Macrobrachium rosenbergii, de Man 1879) one type of freshwater shrimp that is right to be developed on a large scale because these shrimp are of high value when in domestic market demand reaches 20 tons/day. Production of giant prawns in 2012 reached 214.840 tons, while in 2013 it dropped by 203.299 tons (FAO, 2015). The decline in production can be carried out by a relatively slow and low level of growth (Hammed et al., 2000). Constraints in aquaculture business that many farmers complain about one of them is the high price of commercial 
feed. Feed as a source of energy for growth is a significant component of costs in production, namely 40-89 \% (Afrianto and Liviawaty, 2005). Need for feeding efficiency or also called growth efficiency, growth efficiency is the percent of feed given which is converted into growth (Handajani and Wahyu, 2010).

In the control of feed to provide efficiency can be done with gratification. Mastery is one way to reduce feed consumption (Tahe, 2008) and can empty the stomach to increase appetite. Periodic ownership can boost growth speed compared to non-ownership (Rachmawati et al., 2010). Prawns do molting in the growth that is triggered by gastric acid in the formation of calcium ions, therefore to find out the efficiency of feed and the growth that is periodically fastened, it is necessary to research the Effect of periodic fasting on growth and feed efficiency in $M$. rosenbergii.

\section{Material and methods.}

\subsection{Experimental design.}

The materials used in this study are as follows: analytic scales, DO meters, thermometers, scales, sterofoms, aerators, giant prawn lobes, pellets, and nets. The method used in this study is an experimental method using completely randomized design (CRD). Which is a research activity that aims to assess the effect of periodic fasting on growth and feed efficiency in M. rosenbergii, referring to previous experiments in five treatments and three replications. The calculating daily growth rate (DGR), absolute weight growth (AWG), survival rate (SR) according to Effendie (2002), feed efficiency (FF) according to (Afrianto et al., 2005). Fasting periodic of treatment by following this design: P0 as control (without fasting), P1 (a day fasting, a day feeding), P2 (a day fasting two days feeding), P3 (a day fasting three days feeding), P4 (a day fasting four days feeding), and P5 (a day fasting five days feeding).

The sample $M$. rosenbergii with 4-5 cm of total lenght was obtained from the research location which was located at the Brackish Water Cultivation Plant Unit of Probolinggo (IBAP Probolinggo). The sample was placed in a sterofom container that had previously been cleaned. Shrimp Shells Tiles in a sterofom container are given shelter in the form of nets and pipe for hiding places when shrimp are molting, and nets are also used to protect the maintenance container so that it is not disturbed from the outside and so that the shrimp themselves do not jump from the maintenance container. Period of research on periodic granting is carried out 30 days, with treatment totaling six including controls and replications. There are three times each treatment.

Water maintenance to stay awake in good condition, then this study uses an aerator to supply dissolved oxygen and full water replacement is carried out simultaneously with the calculation of daily growth rate and the growth of absolute shrimp weight every ten days. Weighing ten days is also useful for calculating feed requirements according to the weight of giant prawns for the next ten days to feed efficiency. M. rosenbergii gratification treatment is carried out for $1 \times 24$ hours, commercial feeding with $30 \%$ protein content according to daily needs, given twice a day in the morning and evening.

\section{Results and discussion.}

The daily growth rate is weight gain every day during maintenance. The results of the study on the daily growth rate obtained data results as in Figure 1: 


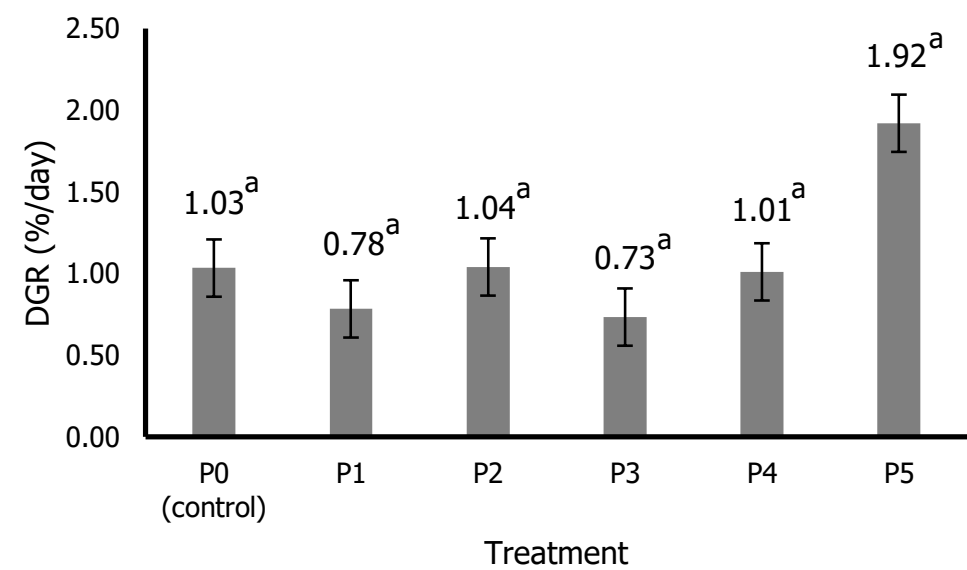

Figure 1. Daily growth rate during fasting periodic

In Figure 1, during periodic grafting of prawns to the daily growth rate for 30 days, compared to the P5 treatment on day 30, possession had the highest average daily growth rate with $1.92 \%$ of the other treatments. The effect of gratification in the effort of emptying the stomach which can increase stomach acid in meeting the body's calcium in the shrimp to trigger skin changes so that the body length increases (Chand et al., 2015). Unlike the case with treatment P1 with a value of $0.78 \%$, P3 with an amount of $0.72 \%$, and P4 with an amount of $1.01 \%$ which has an average daily growth rate below the growth rate of control with an amount of $1.03 \%$. The low P1, P3 and P4 costs are caused by several factors, including increased stress levels and decreased immune system. This was also confirmed by Muralisankar et al (2005), that decreased activity and appetite for shrimp due to increased stress levels.

Periodic mastery could increase the speed of growth. That was because the shrimp has hyperphagia which is a condition of shrimp having an increase in appetite for some 2-3 days after fasting. Increased feed consumption during hyperphagia can provide a sufficient supply of nutrients to meet metabolic needs after fasting so as to increase growth. When associated with water quality, this insignificant result is possible due to the $\mathrm{pH}$ being too alkaline above the ideal $\mathrm{pH}$ condition (Chand et al., 2015).

This condition occurs for ten days of treatment on PK and P5 which then also occurs in all other treatments for 20 days and 30 days of treatment. According to Novotny and Olen (2005), the $\mathrm{pH}$ of water that is not ideal will affect oxygen consumption, respiratory activity, and appetite. This can also be caused when gastric emptying can reduce shrimp activity, increased stress levels and other possibilities explained by Hammed et al. (2000) that is feeding that is not optimal. Nevertheless, there was an increase in 30 days, namely the treatment of P5 which was satisfied periodically.

Absolute weight growth is calculated to determine the weight gain of test animals during maintenance time. The results of the study on the growth of absolute weights obtained data as in Figure 2. During the fasting periodic treatment of giant prawns to absolute weight growth, compared to controls, P5 treatment until 30 days of possession had the most massive total weight growth value with a value of 0.58 among other treatments. Unlike the case with treatment P1 with a value of 0.23 , P3 with a value of 0.22 , and P4 with a value of 0.3 which has an absolute weight growth below the growth rate of the control with a value of 0.31 . This periodic mastery can increase the 
speed of growth compared to without ownership (Rachmawati et al., 2010). As time increases, the growth of giant prawns will include long and massive growth.

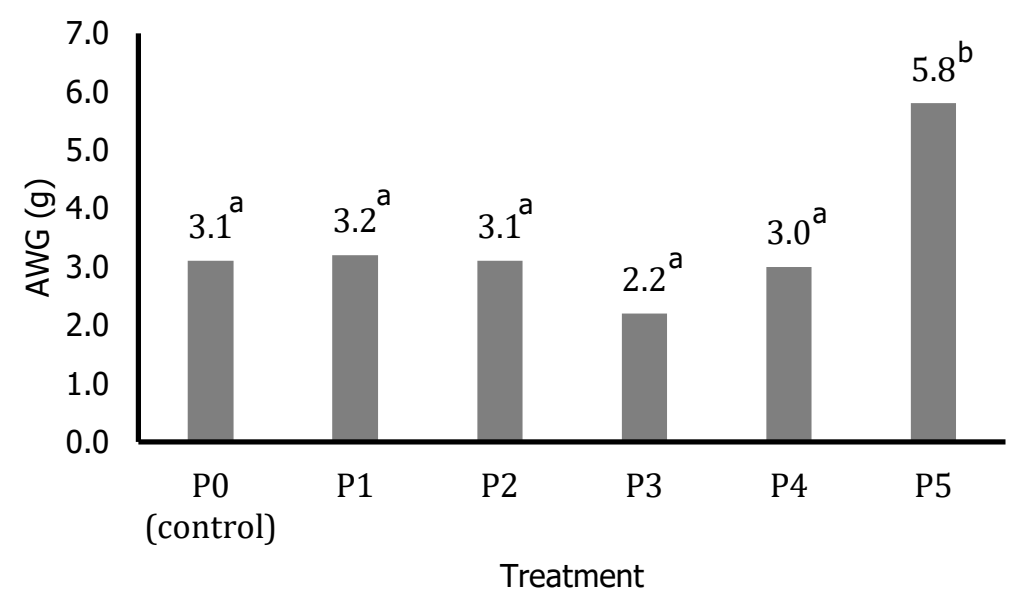

Figure 2. Absolute weight growth during fasting periodic

The results of the analysis of variance in the investigation did not have a significant effect. It means that in this study, the existence of $M$. rosenbergii possession periodically did not have a substantial impact on growth. These results indicate that periodic gratification treatment has the same effect, which means that regular ownership does not affect absolute growth. This provides savings in daily feed consumption even though not much. However, this can also cause the effect of mastering giant prawns to reduce shrimp activity and high levels of stress. Although P2 also has the same value as the control (P0) treatment and compared with the P5 treatment on $30^{\text {th }}$ day the possession has an absolute growth average of the most The periodic mastery can increase the speed of growth and also save money equal or even higher than without ownership (Rachmawati et al., 2010). This is strengthened by the existence of compensatory growth, which is faster growth, compared to normal feeding: Concerning water quality, this insignificant result may also be caused by $\mathrm{pH}$ which is too alkaline over ideal $\mathrm{pH}$ conditions, this condition occurs from 10 days of treatment on PK and P5 until day 30. When related to water quality, according to opinion (Novotny and Olem, 2005) reduced appetite is caused by the $\mathrm{pH}$ of the water which is not ideal.

Feeding efficiency is the ratio of the ratio between shrimp weight gain obtained by the amount of feed consumed by shrimp. The results of the research on feeding efficiency obtained data, as shown in Figure 3. During the periodic treatment of giant prawns for feeding efficiency, compared to controls, P5 treatment on day 30 of possession had the most efficient average prawn feed efficiency among several other treatments with $141.5 \%$. Unlike the case with P3 treatment with a value of $52.7 \%$ and P4 with a value of $65.6 \%$ which has an average feeding efficiency lower than the control treatment with a value of $74.3 \%$. During gratification, P5 treatment is not only the most effective in boosting the daily growth rate and increasing absolute weight but also the most efficient for shrimp feed. Hammed et al(2000) affirms that feeding that is not optimal will lead to a decrease in production, slow growth of giant prawns, and a low survival rate. 


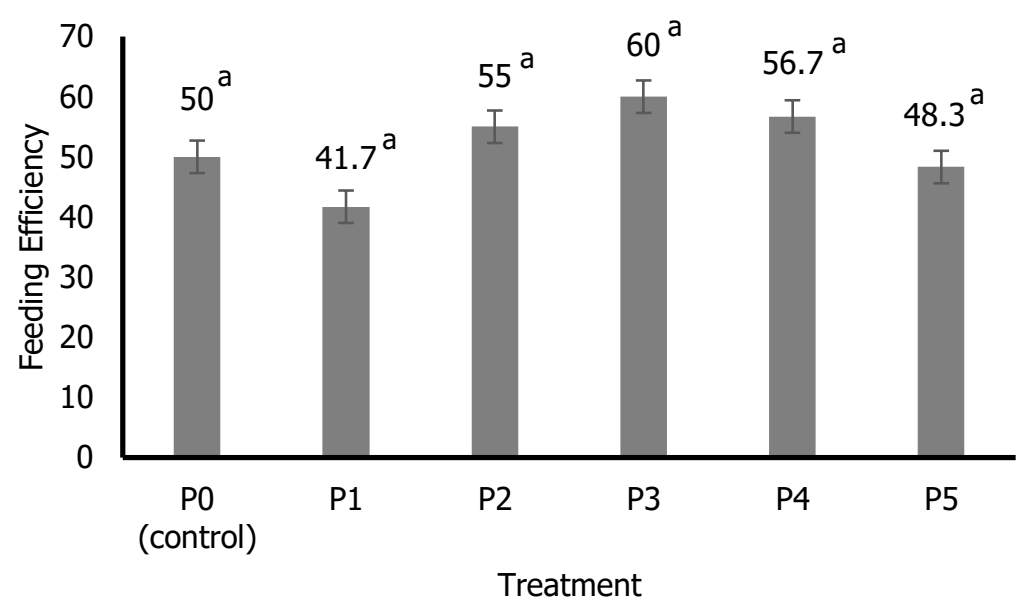

Figure 3. Feed efficiency during fasting periodic

Besides, the results of treatment generally have a high value of feed efficiency, and no significant differences are possible in the cannibalism phenomenon. According to Soetarno (2006), giant prawns have cannibalism, which is the nature of shrimp that eat their fellow humans. This trait grows especially if a maintenance pond is stocked with a high enough density or fewer food reserves. The survival rate is the percentage of survival can also be interpreted as the number of life levels from stocking to the end of maintenance. The results of the study on the survival rate obtained data, as shown in Figure 4:

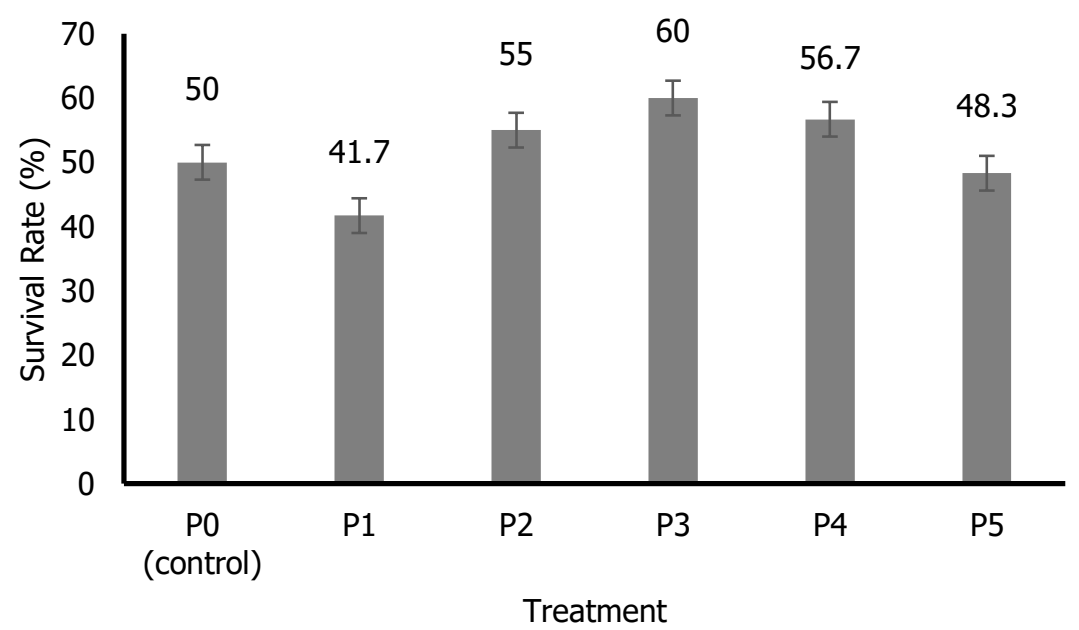

Figure 4. Survival rate during fasting periodic

In Figure 4, as long as periodic grafting of giant prawns is on survival, compared to controls, P3 treatment on 30th day of possession has the highest survival rate of giant prawns among other treatments with a value of $60 \%$. Unlike the case with treatment P1 with a value of $41.7 \%$ and P5 with a value of $48 \%$ which has an average survival rate under control with an amount of $50 \%$. On the explanation of the previous treatment, P2 and P5 were effective in driving the growth rate of daily giant prawns; P5 treatment effectively encourages the growth of absolute weight of giant prawns; and treatment of P1, P2, and P5 efficiently on shrimp feeding. Although P5 has higher effectiveness and efficiency, it turns out that the giant prawns on P5 have a lower survival rate than controls and other treatments. Likewise, P1 treatment which has a same survival rate, but effectively encourages absolute and efficient weight growth on feeding. 
Compared to controls, P2, P3, and P4 treatments have a higher survival rate. However, the treatment of P2 has a low absolute weight growth. Whereas P3 treatment has a small daily growth rate and is not efficient for feeding. On the other hand, P4 treatment has a low daily growth rate and is not suitable for food. In the field of production, the survival rate is significant, especially Hammed et al. (2000) also stressed that the decline in output of giant prawns could be caused by the relatively slow growth of giant prawns and low survival rates. Granting 24-hour results in a higher graduation rate than the 24-hour and more than 24 -hour duration of treatment, which is $80 \%$ (Perez-Rostro et al., 2006). During the study, pH conditions that were too alkaline above ideal pH conditions might be factors that cause periodic gratification to have no significant effect on the survival rate of giant prawns.

\section{Conclusions}

The periodic fasting does not have a significant effect on the daily growth rate, absolute weight growth, and feeding efficiency in $M$. rosenbergii. Looking at growth and survival, this method of gratification could be used as an alternative to more economical feed efficiency.

\section{References}

Afrianto E dan E Liviawaty. 2005. Pakan Ikan. Kanasius. Yogyakarta.

Chand BK, Trivedi RK, Dubey SK, Rout SK, Beg MM, Das UK. 2015. Effect of salinity on survival and growth of giant freshwater prawn Macrobrachium rosenbergii (de Man). Aquaculture Reports. 2: 26-33.

Effendie MI. 2002. Biologi perikanan. Yayasan Pustaka Nusantama. Yogyakarta.

FAO. 2015. Species Fact Sheets: http://www.fao.org/fishery/species/2608/en.

Hameed ASS, Charles MX, Anilkumar M. Tolerance of Macrobrachium rosenbergii to white spot syndrome virus. Aquaculture. 183(3-4): 207-213.

Handajani H, Wahyu W. 2010. Nutrisi Ikan. UMM Press. Malang.

Thirunavukkarasu M, Bhavan PS, Radhakrishnan S, Seenivasan C, Srinivasan V. 2016. The effect of copper nanoparticles supplementation on freshwater prawn Macrobrachium rosenbergii post larvae. Journal of Trace Elements in Medicine and Biology. 34: 39-49.

Perez-Rostro CI, Perez-Fuentes JA, Hernandez-Vergara MP. Biofloc, a technical alternative for culturing Malaysian Prawn Macrobracium rosenbergii. Sustainable Aquaculture Techninques. Chapter 3: 87-105.

Rachmawati FN, Susilo U, Sistina Y. 2010. Respon fisiologi ikan nila (Oreochomis niloticus) yang distimulasi dengan daur pemuasaan dan pemberian pakan kembali. Seminar Nasional Biologi. 492-499.

Soetarno. 2006. Molting udang galah (Macrobranchium rosenbergii). CV. Sagung Seto. Jakarta.

Tahe S. 2008. Pengaruh starvasi ransum pakan terhadap pertumbuhan, sintasan dan produksi udang vannamei (Lipopenaeus vannamel) dalam wadah terkontrol. Jurnal Riset Akuakultur. 3(3): 401-412. 